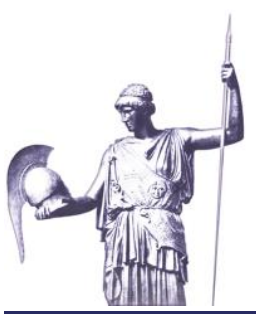

Connections: The Quarterly Journal

ISSN 1812-1098, e-ISSN 1812-2973

James Howcroft, Connections QJ 17, no. 2 (2018): 77-81

https://doi.org/10.11610/Connections.17.2.06

Practitioners' Views

\title{
The Future of Terrorism: The Practitioners' View
}

\section{James Howcroft}

George C. Marshall European Center for Security Studies, https://www.marshallcenter.org

\begin{abstract}
In this essay, the author-an experienced intelligence officer and currently lead for the counter-terrorism program at the George C. Marshall European Center for Security Studies-reviews the future developments of international terrorism in three main areas: motivations; tactics, weapons and technology, and targets.
\end{abstract}

Keywords: terrorism, counterterrorism, War or Terrorism.

The 9/11 Commission identified "lack of imagination" within the counter-terrorism community as a key reason for the failure to stop the attack on the World Trade Center and Pentagon in 2001. The failure to realize that airplanes themselves could be used as weapons contributed to the fact that the plot was not detected, and appropriate counter-measures were not taken. It is therefore important for counter-terrorism professionals to try to think from the terrorists' perspective and to consider possible ways they might adapt and innovate in the future.

The Program on Terrorism and Security Studies (PTSS) at the George C. Marshall European Center for Security Studies in Garmisch-Partenkirchen brings together counter-terrorism professionals and practitioners from around the world for a month twice a year to study contemporary terrorism and the tools and strategies needed to combat it. The 68 participants from 48 countries who attended the PTSS in July 2018 were tasked to use their informed imagination and to think of plausible ways that terrorism might evolve within the next ten years. Participants were asked to provide their assessments in three main areas: motivations, tactics/ weapons/technology and likely targets. 


\section{Motivations}

The group concluded that Salafi-jihadist ideology will continue to play a major role in global terrorist motivations in the near term. A growing youth population with limited economic and social opportunities, exposed vicariously to excitement and adventure via modern social media, will be susceptible to those peddling real-life adventure and purpose through membership in a terrorist organization - as was done so successfully by ISIS in recent years. Growing economic inequality, combined with frustration caused by limited employment opportunities for growing youth populations was thus noted as a continued driver for jihadist terrorism, but also for a potential resurgence in left-wing politically motivated violence.

As sizable populations move across borders due to either violence, climate issues or lack of economic opportunity, the growth of radical, anti-immigrant and anti-integration factions established to 'defend' the host nations' identity against foreign cultures and religions is likely. Just as probable will be the formation of reciprocal 'self-defense' groups from within the immigrant community ready to use violence to achieve political power to protect their group against perceived marginalization. Existing terrorist organizations could just as well recruit from within the vulnerable and marginalized immigrant community by styling themselves as their defenders against a hostile or uncaring host nation's population.

Finally, a backlash against advanced technology applications which replace unskilled labor may also become a concern. Economic inequality and job losses caused by technology will most likely be a challenge which governments will find difficult to address, leading to grievances ripe for exploitation. In such a scenario, the prospect of 'technophobe' terrorism is not unrealistic.

\section{Tactics, Weapons and Technology}

The PTSS participants noted that guns and explosives were the most widespread type of weaponry in use today. There was little expectation that this would change dramatically over the next decade. Guns and bombs have proven effective and are relatively easy to obtain and employ. While a great deal of resources have been devoted by governments to address the threat to civil aviation, terrorists have made widespread use of ordinary cars and trucks to carry out attacks in numerous venues to include Nice, Barcelona, Berlin, London, Stockholm, and New York City. Due to the relative ease of carrying out these attacks and their recent successes, there is little reason to expect a drop in this particular tactic. Technological applications to expand the use of driverless cars and trucks present advantages for society, but also challenges requiring them to be safeguarded to prevent their use in remote attacks against civilian or governmental targets.

Terrorists have already started to use drones, at times in swarms, as observed within the past year both in Syria and Iraq. The proliferation of commercially- 
available, ever more-capable drones and the expansion of their roles in the business and delivery sectors will inevitably result in more frequent use by terrorists. The use of drones in the attempted assassination of Venezuelan President Maduro on the 4th of August 2018 is an early example of the expanded threat that drones will play in the future. The inevitable continued commercial advances in drone miniaturization and programming will present challenges for security services already struggling to adapt to the rapid evolution in drone technology.

The potential use of a weapon of mass destruction (WMD), while perhaps still unlikely, remains a tactic with the potential for outsized impact and influence on a civilian population. Increased urbanization and ever-increasing population densities will multiply and spread a WMD's effect, whether it be chemical, biological or radiological in nature. Instantaneous and unfiltered social mediahosted communication within populations would provoke panic and potentially overwhelm official attempts to provide accurate and appropriate information regarding the true nature and extent of the threat to its citizens.

There already exists an understanding among counter terrorism practitioners that there is convergence of actions and activities between organized criminal organizations and terrorists. This is neither unforeseen, novel nor calamitous and in some cases, it can open opportunities for exploitation by security officials. Participants noted that this terror-crime linkage is likely to grow and deepen, complicating efforts by governmental agencies to address this networked threat.

The cyber realm is increasingly exploited by criminals and financial extortionists and it seems reasonable to expect terrorists, learning and adapting from their criminal brethren, to use this methodology to threaten governments to accede to their political demands. Indeed, cyber-skilled terrorists will increasingly exploit online vulnerabilities as governments and everyday consumers rely ever more on the internet. Looking to the future, the rapidly expanding 'Internet of Things,' which is used to run devices and applications central to daily life, is likely to be susceptible to disruption, manipulation and coercion. With cyber operations in mind, it is worth highlighting the fact that most current definitions or understandings of terrorism contain an element of violence or threat of violence. Perhaps this understanding needs to be expanded to include actions which threaten the safety and well-being of populations. Examples might be threats or actual attacks on water or electricity supplies, banking, or air traffic control networks that do not necessarily result in physical destruction.

\section{Targets}

The PTSS participants noted that public transportation networks, which are difficult to protect and expose large numbers of civilians to attack, are likely to remain targeted. While airlines and trains have been attacked in the past, ferries and cruise ships were specifically identified as transportation modes which appear to offer a number of advantages as targets from a terrorist perspective. Other soft targets like street festivals, sporting events and music venues will also remain attractive. Tourist locations that draw a large number of international 
visitors are difficult to protect in a way that does not deter travelers. For terrorists, attacking such a target ensures widespread global reporting. The 2015 attacks at the Bardo Museum and Sousse beach in Tunisia killed citizens from fourteen nations throughout Europe, Asia, and South America. Such attacks of course also result in significant economic damage for the countries concerned.

The participants further noted the increasing likelihood of attacks by and on children. Indonesia witnessed attacks by families with children in May 2018 and children mounted attacks in Chechnya in August. As nations receive back their citizens who joined Al Qaeda and ISIS in Syria and Iraq they have struggled to determine and apply the proper approach and methodology to address children, the so-called "cubs of the caliphate." Terrorism attacks involving children, either as attackers or victims, bring forth strong emotion. No population within societies is more precious than children. Attacks against schools are generally high impact and low-risk. Schools are generally expected to be safe places for children. School attacks shatter this assumption, generate tremendous publicity and arouse intense emotions.

A government, under tremendous pressure from an emotional public, would need to take extreme and public measures to demonstrate its ability to protect the most vulnerable in society. Extreme, emotional response by government security forces would almost inevitably result in hasty, ill-prepared and counterproductive measures. Brutal school attacks, while generating widespread publicity and fear, run the risk of galvanizing public support against a terrorist group, as was the case in the 2014 Tehrik-I-Taliban school massacre in Peshawar, Pakistan.

If growing inequality and economic woes are increasingly relevant motivators for terrorism in the future, the headquarters and other physical and human assets of large multinational corporations will likely be attractive targets. Attacks could be carried out against infrastructure and personnel in less security-capable countries, yet still have a global impact because of the reach of the targeted corporation. Attacks against faceless multinationals, usually owned and run by foreigners, as a blow against the inequality suffered by the population, would be an attractive terrorist narrative to gain sympathy and support for its actions. Similarly, companies specializing in technology and automation are likely to present attractive targets for 'technophobes.' Governments would be hard pressed to justify spending scarce resources to defend wealthy corporations instead of their own citizens, meaning these multinationals would need to be largely dependent on themselves for warning, protection and deterrent measures, resulting in further privatization in the Counter Terrorism field.

The motivations, tactics and targets identified and discussed by the PTSS participants are not exhaustive by any means but provide an informal consensus by an experienced global team of counter terrorism practitioners. The possibilities 
identified require no fantastic technological advances, they are adaptations of tools, devices and applications that are widely and inexpensively available to ordinary citizens today and in which terrorists have already shown an interest. Similarly, the likely future grievances the participants identified are already present on the front pages of newspapers around the world. Once a grievance and possible weapons are identified, ascertaining potential targets is certainly doable if analysts and practitioners allow themselves to examine the threat from the terrorists' perspective. Doing so will enable government leaders to make informed decisions regarding the allocation of finite resources in a way best suited to defend their citizens and their way of life.

\section{About the author}

James Howcroft serves as the Director of the Program on Terrorism and Security Studies at the George C. Marshall Center. Professor Howcroft retired as a Colonel after 30 years as an Intelligence Officer in the United States Marine Corps. He served in a wide range of Marine Corps tactical and operational intelligence billets, from Infantry Battalion up to the Marine Expeditionary Force level. His combat tours include duty with the 2nd Marine Division in Operation Desert Storm and tours of duty as the Assistant Chief of Staff for Intelligence (G2) with both the 1st Marine Division and then the 1st Marine Expeditionary Force in Iraq.

E-mail: james.howcroft@marshallcenter.org. 